International Journal of Advancement in Life Sciences Research

Online ISSN: 2581-4877

journal homepage http://ijalsr.org

Original Article

\title{
Effect of Sambiloto (Andrographis paniculata) Leaves against Cholesterol Levels in Wistar Rats with Atherogenic Diet
}

\author{
Rizky Dzariyani Laili*, Arie Dwi Alristina, Rossa Kurnia Ethasari, Dewinta Hayudanti \\ Department of Nutrition, Sekolah Tinggi Ilmu Kesehatan Hang Tuah Surabaya, Jl. Gadung No. 1, Surabaya, \\ Indonesia
}

${ }^{*}$ Correspondence E-mail : rizkylaili@stikeshangtuah-sby.ac.id

\begin{abstract}
Introduction : The risk of atherosclerosis increases when elevated blood cholesterol levels. Flavonoids may help inhibit the absorption of fat, which indirectly helps in lower cholesterol levels.Flavonoids are widely available on the Andrographis paniculata leaves (APL).This study aims to examine the effect of flavonoids in APL stewto lower the cholesterol levels. Material and Methods: This research was carried out using five different groups of Wistarrats. Each group consists of five Wistar rats. Group (K-) received normal diet, group $(\mathrm{K}+)$ received atherogenic diet and three groups of atherogenic diets rats that pre-treated with three different doses $(0.6,1.2$, and $2.4 \mathrm{~g} / \mathrm{day})$ of APL leaf stew. APL stew is orally gavaged for 60 days. The cholesterol blood serum was analyzed using the CHOD-PAP method. Statistical analysis using One-Way ANOVA and Post-Hoc Tukey. Results : The results showed a significant difference in cholesterol levels between the groups of theatherogenic diet with other treatment groups $(p=0.000)$. When compared with thenormal diet group, treatment with 1.2 $\mathrm{g}$ and $2.4 \mathrm{~g}$ of APL produce cholesterol levels not significantly different.APLstew has been shown to inhibit the elevated levels of serum cholesterol in male Wistar rats that fed with the atherogenic diet which contributed $54.8 \%$. While fat intake increased the cholesterol level by $16.3 \%$.Both APL stew and fat dose intake together affect the formation of cholesterol with a contribution of $69.2 \%$. Conclusion : The dose that is considered as the most effective in lowering cholesterol is $2.4 \mathrm{~g}$ becauseit producescholesterol level closest to normal.
\end{abstract}

Keywords: Andrographis paniculata; atherogenic diet; cholesterol

\section{Introduction}

Prevalence of hypercholesterol is $39.6 \%$ women and $30 \%$ men in Riskesdas, Indonesia 2013. WHO data in 2015 showed that deaths worldwide caused by heart and vascular disease by $45 \%$. Riskesdas 2018 shows a prevalence of heart disease of $1.5 \%$. This is in line with research conducted by Sample Registration System Indonesia in 2014 showing that the highest cause of death in Indonesia from heart disease is $12.9 \%$ (KKRI 2019).
Consumption of high-fat, low-fiber, and antioxidants is one of the risk factors for atherosclerosis. Saturated fatty acids can increase cholesterol levels, while flavonoids can help inhibit the absorption of fats that indirectly help lower cholesterol levels (Widjajakusuma et al. 2019).

At the moment the group of drugs that are widely used is the group of statins associated with muscle disorders through the mechanism of inhibition of HMG-CoA enzymes that can decrease the production of mevalonate. In 
addition, statins can also provide side effects in the form of discomfort in the stomach in the form of bloating and abdominal pain (Hariadini, A.L., 2020). One of the natural ingredients used for cholesterol-lowering is APL. APL contains tannins and flavonoids in the form of andrographin as antioxidants. APL is known as a king of bitter reported as an antiinflammatory, immunomodulator, atherosclerosis, and antihyperglycemic (Nugroho et al. 2012; Dai et al.2019). In this study, we determined the effects of APL stew against decreasing cholesterol levels in ratswith atherogenic diet.

\section{Materials and Method}

Dry APLwas purchased from Materia Medica, Batu, East Java, Indonesia. A marker for cholesterol serum was obtained from the Anatomy Laboratory, University of Brawijaya.

\section{Extraction of $A P L$}

The dried APL was milled with ablender and sieved 80 mesh. The powder of APL was weighed as much as 50 grams and heated in $50 \mathrm{cc}$ aquades at $100^{\circ} \mathrm{C}$ for 5 minutes. Next, it was refrigerated until the temperature of $40^{\circ} \mathrm{C}$. It was then filtered and added aquades until the volume is $50 \mathrm{cc}$.

\section{Animal Experiments}

Male Wistar rats weighing 150-200 g were placed in the control room with a cycle of 12 hours of light, 12 hours of darkness. Animals were fed and drank throughout the day. After 1 week of acclimation, the rats were randomly divided into 5 groups (5 rats/group). Negative control (K-) of a normal diet and positive control $(\mathrm{K}+)$ are given an atherogenic diet and given mineral water orally every day. The other three groups were given an atherogenic diet and administered doses of APL stew ( 0.6, 1.2 , and $2.4 \mathrm{~g} /$ day) for 60 days. The protocol of the animal experiment was approved by the ethical committee of University of Brawijaya, Malang, Indonesia (No. 0305/EC/KEPK-S1GZ/10).

\section{Cholesterol Blood Serum Analysis}

Blood serum cholesterol levels in Wistar rats were measured on day 61. Rat blood serum was taken from the heart of the rat as much as $150 \mathrm{~mL}$. Serum samples are then taken as much as $100 \mathrm{cc}$ and mixed with $1000 \mathrm{cc}$ reagent kit then homogenized. The mixture is incubated at $37^{\circ} \mathrm{C}$ for 5 minutes and read absorbance at a wavelength of $500 \mathrm{~nm}$.

\section{Statistical Analysis}

Blood serum cholesterol analysis was performed using One-Way ANOVA at the 95\% of confidence level $(\alpha=0.05)$. if the ANOVA calculation showed significant differences $(p<0.05)$, then continued with the Post-Hoc Tukey test at $95 \%$ of confidence level ( $\alpha=$ 0.05).

\section{Results}

\section{Effects of APL Stew on Cholesterol Levels of Wistar Rat}

Serum cholesterol levels of rat blood after being given APL stew treatment for 60 days calculated using chod-PAP method.Table 1 shows the obtained cholesterol levels. Cholesterol levels in rat blood serum differ significantly $(p<0.05)$. Cholesterol levels in group $\mathrm{K}+$ were $183.40 \pm 15.04$ higher than the P2 group (157.60 14.77$)$, while the P4 cholesterol level $(122.20 \pm 5.89)$ was close to the cholesterol level of group K$(108.60 \pm 7.40)$. Values are means of triplicate samples.

Blood cholesterol level analysis of Wistar rats using One-way ANOVA showed that there were significant differences from the five treatment groups with a value of $p=0.000$ $(\alpha=0.05)$. The analysis continued by using Post-Hoc Tukey to find out the differences between groups.

Table 1. Cholesterol Blood Serum Rats Wistar (mg/dl)

\begin{tabular}{cc}
\hline Treatment & Cholesterol Blood Serum \\
\hline $\mathbf{K}-$ & $108.60 \pm 7.40^{\mathrm{a}}$ \\
$\mathbf{K}+$ & $183.40 \pm 15.04^{\mathrm{b}}$ \\
$\mathbf{0 . 6} \mathbf{~ g}$ & $157.60 \pm 14.77^{\mathrm{c}}$ \\
$\mathbf{1 . 2} \mathbf{~ g}$ & $129.60 \pm 8.98^{\mathrm{d}}$ \\
$\mathbf{2 . 4} \mathbf{~ g}$ & $122.20 \pm 5.89^{\mathrm{a}}$ \\
\hline
\end{tabular}

Note : Different letters demonstrate a significance $(p<0.05)$ in the same rows according to Post Hock Tukey test

\section{Effects of APL Stew on Wistar Rat Weight}

The weight of Wistar rat was measured before and after treatment. The measurements were taken once a week to determine whether there 
is any increase in weight of Wistar rat. The weight analysis was conducted using the Oneway ANOVA statistical test. The initial weight results show that there was no significant difference with the value $p=0.258$. Therefore, it concluded that the weight of the Wistarrat before the treatment was the same (homogeneous) in all treatment groups as seen in table 2, while the weight gain results also show no significant difference with $\mathrm{p}=0.068$.

Table 2. Body Weight Rats Wistar

\begin{tabular}{cccccc}
\hline Weeks & \multicolumn{5}{c}{ Treatment } \\
\cline { 2 - 5 } & $\mathrm{K}-$ & $\mathrm{K}+$ & $0.6 \mathrm{~g}$ & $1.2 \mathrm{~g}$ & $2.4 \mathrm{~g}$ \\
$\begin{array}{c}\text { Early Body } \\
\text { Weight (g) }\end{array}$ & $120.4 \pm 8.41^{\mathrm{a}}$ & $133_{ \pm} 13.78^{\mathrm{a}}$ & $121.6 \pm 6.87^{\mathrm{a}}$ & $125 \pm 6.55^{\mathrm{a}}$ & $125.6 \pm 8.38^{\mathrm{a}}$ \\
Weight Gain (g) & $68.2 \pm 21.29^{\mathrm{a}}$ & $103.20 \pm 7.67^{\mathrm{b}}$ & $85.60 \pm 20.95^{\mathrm{a}}$ & $113.7 \pm 51.09^{\mathrm{b}}$ & $114 \pm 25.37^{\mathrm{b}}$ \\
\hline
\end{tabular}

Note : Different letters demonstrate a significance $(\mathrm{p}<0.05)$ in the same rows according to One-Way Anova test

\section{Relationship between Dose of APL Leaf and Cholesterol Levels}

The results of a simple linear regression analysis test with cholesterol level-dependent variables and independent variables of APL leaf grafting dose can be known that cholesterol levels in the P2, P3, and P4 treatment groups were negative and significant with the given dose of APL leaf grafts. Itrevealed that the smaller the dose of leaf stews given, the greater the cholesterol levels in the blood of the Wistarrat. This is reinforced by a probability value of 0.001 . The amount of cholesterol level relationship with the dose of APL leaves is 0.740 .

The magnitude of the contribution of the effect of the dose of APLleaf on cholesterol levels in the treatment group $\mathrm{P} 2, \mathrm{P} 3$, and $\mathrm{P} 4$ were proven through the results of linear regression test. Thecalculation test $R$ square show a result of 0.548 . This concluded that the dose of leafy stews of APL has a contribution of $54.8 \%$ in affecting cholesterol levels of Wistar rats.

\section{Relationship Between Dose of APL Leaf and Fat Intake on Cholesterol Levels}

The effect of fat intake and dose of APL leaf was given to cholesterol levels bymultiple linear regression tests were conducted. The results show that the fat intake of animals had a positive relationship, the greater the intake of fat, the greater the measurable cholesterol levels. The magnitude of the relationship between fat and cholesterol levels is 0.403 with a probability of 0.023 . While the dose of APLleaf has a negative relationship to cholesterol levels. It was expressed that the larger the dose of leaf APLstewgiven, the smaller the measured cholesterol value. The relationship between the dose of leafy DekokAPL and cholesterol levels is 0.357 .

The amount of fat intake contribution and the dose of APLleaf stew given, from the results of linear regression tests are known that the dose of leaf stews and animal fat intake try to contribute $69.2 \%$ to the formation of cholesterol serum levels.

\section{Relationship of Energy Intake and Nutrients on Cholesterol Levels}

Intake of macronutrients, in this case only fats that have a positive relationship with cholesterol levels in Wistar rat, the greater the fat consumed by Wistar rat, the greater the cholesterol levels in serum measured. The magnitude of the relationship between fat intake and cholesterol levels was 0.403 with $p$ $=0.023$ which was significant. In addition to fat, weight gain also had a positive relationship with cholesterol levels in the Wistar rat, the higher the cholesterol levels of the Wistar rat, the higher the weight gain of the Wistar rat. However, itdid not show a significant association with $p=0.355$. The weight gain was influenced by fat intake which increased the cholesterol level too.

The amount of contribution of macronutrients in affecting cholesterol levels was showed by linear regression tests. The results show that adjusted value of $R$ square analysis of the influence of macronutrient intake on cholesterol level is 0.216 . This shows that carbohydrates, fats, and proteins contributed $21.6 \%$ in producing cholesterol levels in serum rat. 
The contribution of carbohydrates to the formation of cholesterol levels in animal serum trials from the results of linear regression tests showed that carbohydrate intake contributed by $19.3 \%$ in affecting cholesterol levels inWistar rat.In addition to carbohydrate intake, fat intake in the diet of each treatment group also had a role in the formation of cholesterol in this study. The relationship of fat intake with cholesterol levels in ratshows that fat intake from the diet has a role of $16.3 \%$ in affecting cholesterol levels. While other macronutrients, namely protein, also contributed to measure cholesterol levels at the end of the study. Linear regression test results show that protein contributed $19.9 \%$ in determining cholesterol levels of Wistar rat.

\section{Discussion}

The formation of body cholesterol comes from two sources, namely, those derived from foods called exogenous cholesterol, and cholesterol produced by the body itself called endogenous cholesterol. If cholesterol comes from food is small, to meet the needs of other tissues and organs, then the synthesis of cholesterol in the liver and intestines will increase. Likewise, if the amount of cholesterol in the diet increases then the synthesis of cholesterol in the liver and intestines will decrease (Violi et al. 2002, Widyani, R., 2019).

So the importance of energy for our body must still be considered the balance because if the energy value of food was eaten is greater than the energy lost due to heat and work, or that is censored by the body, then energy will be stored and will be able to increase weight (Lakshmia et al. 2014).

A diet high in fat can result in the presence of LDL oxidation. Increased LDL oxidation is caused by high triglyceride levels that can convert VLDL metabolism into a large form of VLDL, this can damage HDL which will eventually complicate the cholesterol content of blood vessels (Lakshmia et al. 2014, Widyani, R., 2019).

Plants that are efficacious to lower the levels of cholesterol and high triglycerides including plants APLhave a mechanism of action that is flavonoids as antioxidants that inhibit the oxidation of human LDL. Flavonoids also inhibit platelet aggregation in the blood which plays a role in reducing the risk of heart disease (Violi et al. 2002). Flavonoids also affect cholesterol metabolism directly in hepar. Hypotheses that support the decrease in cholesterol levels and the activity of HMG-CoA reductase and sterol enzyme 0 acyltransferase-2 in cholesterol metabolism after giving flavonoids in rats (Lakshmia et al. 2014).

APL also contains tannins that have a mechanism of action to reduce the oxidative stress of macrophages and inhibit the formation of atherosclerosis. Tannins in the body will bind to the body's proteins and will coat the intestinal wall so that the absorption of fat is inhibited (Sudarmi et al. 2018). In addition, tannins protect the intestines against unsaturated fatty acids. The process of protection is carried out by tannins in the form of compaction of the mucus layer of the gastrointestinal tract thus inhibiting the absorption of food substances (including cholesterol fats) by the gastrointestinal tract (Liu et al. 2020). In addition, tannins are known to spur the metabolism of glucose and fat, so that the deposits of these two sources of calories in the blood can be avoided, meaning cholesterol and blood sugar drop (Bharati et al. 2011).

Decreased cholesterol levels are caused by the presence of antioxidant effects, improving endothelial function, and improving the balance of nitrite oxide. In addition, the decrease in cholesterol levels in the blood is due to the APL contained fiber and vitamins called can lower cholesterol and triglyceride levels with the help of fiber that binds to fatty acids free of bile acids which are then released through feces. Fiber is also fermented by microflora in the intestine producing acetic acid, propionate, and butyric acid which can inhibit cholesterol synthesis (Warditiani et al. 2020).

Saponins are also present in APL, the role of saponins against cholesterol reduction is that saponins can form complex bonds that are insoluble with cholesterol (from food) in the intestines so that the cholesterol can not be absorbed. In addition, saponins can combine with bile acids and exogenous cholesterol 
forming rattle which also cannot be absorbed by the intestines. Then saponins can also increase exogenous cholesterol by fiber, so it cannot be absorbed by the intestines (Agrawal and Pandey 2019).

The andrographolide effect in stimulating the immune system in the body, and especially phagocytic activity that stimulates the production and flow of bile, protects the hepar from toxins, against the damage effects caused by free radicals. Andrographolide also showed protective activity in the fight against chemical-induced toxicity (Polash et al. 2017; Soltani et al. 2021; Rachmani E. 2019). APL serves as an appetite enhancer, but high doses of APL can result in nausea vomiting, bad stomach and loss of appetite (Mustafa et al. 2010). However, from various studies conducted, in general APL does not cause serious side effects, so it is safe to consume.

\section{References}

Agrawal, R.C. and Pandey, P., 2019. Screening of AndrographisPaniculata Extract For Antioxidant And Genotoxic Activities. International Journal of Research-GRANTHAALAYAH, 7(6), Pp.132-142.

Bharati, B.D., Sharma, P.K., Kumar, N., Dudhe, R. And Bansal, V., 2011. Pharmacological Activity OfAndrographisPaniculata: A Brief Review. Pharmacology online, 2(1), P.10.

Dai, Y., Chen, S.R., Chai, L., Zhao, J., Wang, Y. And Wang, Y., 2019. Overview Of Pharmacological Activities of Andrographis paniculata and Its Major Compound Andrographolide. Critical Reviews in Food Science and Nutrition, 59(Sup1), Pp.S17-S29.

Hariadini, A.L., 2020. Hubungan Tingkat Pengetahuan Dan Ketepatan Penggunaan Obat Simvastatin Pada Pasien Hiperkolesterolemia Di Apotek Kota Malang. Pharmaceutical Journal OfIndonesia, 5(2), Pp.91-96.

KKRI (2019) http://p2ptm.kemkes.go.id/kegiatanp2ptm/pusat-/hari-jantung-sedunia-his-tahun-2019jantung-sehat-sdm-unggul. Accessed at 05/29/2021

Lakshmia, V., Srivastav, S., Khanna, A.K., Mahdi, A.A. And Agarwal, S.K., 2014. Lipid Lowering Potential of Andrographis paniculata (Nees). The Journal of Phytopharmacology, 3(2), Pp.124-129.

Liu, Y.T., Chen, H.W., Lii, C.K., Jhuang, J.H., Huang, C.S., Li, M.L. And Yao, H.T., 2020. A Diterpenoid, 14-Deoxy-11, 12Didehydroandrographolide, In AndrographisPaniculata Reduces Steatohepatitis

\section{Conclusion}

The method used in this study is a preventive method, where APL leaf stew is given in conjunction with an atherogenic diet. The administration of leaf stews APL decreased the cholesterol levels in Wistar rats.The effective dose of APL leaf stew for lowering the total cholesterol level is 2.4 grams.

\section{Acknowledgments}

The authors wish and sincerely thank to authority of Sekolah Tinggi IImu Kesehatan Hang Tuah Surabaya, Indonsia for providing necessary laboratory facilities.

\section{Conflicts of Interest}

The authors declare no conflict of interest.

And Liver Injury In Rat Fed A High-Fat And HighCholesterol Diet. Nutrients, 12(2), P.523.

Mustafa, R.A., Hamid, A.A., Mohamed, S. And Bakar, F.A., 2010. Total Phenolic Compounds, Flavonoids, And Radical Scavenging Activity Of 21 Selected Tropical Plants. Journal of Food Science, 75(1), Pp.C28-C35.

Nugroho, A.E., Andrie, M., Warditiani, N.K., Siswanto, E., Pramono, S. And Lukitaningsih, E., 2012. Antidiabetic AndAntihiperlipidemic Effect of AndrographisPaniculata (Burm. F.) NeesAndAndrographolide In High-Fructose-Fat-Fed Rats. Indian Journal of Pharmacology, 44(3), P.377.

Polash, S.A., Saha, T., Hossain, M.S. And Sarker, S.R., 2017. Investigation of The Phytochemicals, Antioxidant, And Antimicrobial Activity of The AndrographisPaniculata Leaf And Stem Extracts. Advances InBioscience And Biotechnology, 8(05), P.149.

Rachmani, E.P.N., 2019. Aktivitas hipoglikemik Dan Hipolipidemik Fraksi Flavonoid HerbaSambiloto (Andrographis paniculata (Burm. F.) Ness.): Efek In Vivo PadaTikus Yang Diinduksi Fruktosa Dan Lemak Tinggi Serta Kajian In Vitro PadaEnzim AlfaAmilase, Alfa-Glukosidase Dan Antioksidan (Doctoral Dissertation, Universitas Gadjah Mada).

Soltani, S., Boozari, M., Cicero, A.F., Jamialahmadi, T. And Sahebkar, A., 2021. Effects of Phytochemicals on Macrophage Cholesterol Efflux 
Int J Adv Life Sci Res. Volume 4(3)26-31

Capacity: Impact on Atherosclerosis. Phytotherapy Research.

Sudarmi, M., Darmini, W. And Wartini, M., 2018, October. Activity OfSambiloto Extract (AndrographisPaniculataNess) In Reducing Total Blood Cholesterol Levels Hypercholesterolemia Rats. In International Conference On Applied Science And Engineering (ICASE 2018) (Pp. 120122). Atlantis Press.

Violi, F., Pignatelli, P. And Pulcinelli, F.M., 2002. Synergism Among Flavonoids In Inhibiting Platelet Aggregation And H. Circulation, 105, P.E53.

Warditiani, N.K., Sari, P.M.N.A., Ramona, Y. And Wirasuta, M.A.G., 2020. Molecular Pharmacology Study of Andrographolide Extracted From Andrographis paniculata on Atherosclerosis Preventive Effect. Systematic Reviews In Pharmacy, 11(9), Pp.201-206.
Widjajakusuma, E.C., Jonosewojo, A., Hendriati, L., Wijaya, S., Surjadhana, A., Sastrowardoyo, W., Monita, N., Muna, N.M., Fajarwati, R.P., Ervina, M. And Esar, S.Y., 2019. Phytochemical Screening And Preliminary Clinical Trials of The Aqueous Extract Mixture of Andrographis paniculata (Burm. F.) Wall. Ex Nees And Syzygium polyanthum (Wight.) Walp Leaves In Metformin Treated Patients With Type 2 Diabetes. Phytomedicine, 55, Pp.137147.

Widyani, R., 2019. Potency of Herbal Plants Formulation As Anticholesterole Agent: In Vitro Studies. Systematic Reviews in Pharmacy, 10(2), Pp.253-258. 